\title{
THE EFFECT OF INTRAVENOUSLY ADMINISTERED ACETYLCHOLINE ON THE GLYCOCONJUGATE COMPOSITION IN GOBLET CELLS OF THE TRACHEAL EPITHELIUM IN RABBITS
}

\author{
L. VAJNER ${ }^{1}$, J. UHLÍK ${ }^{1}$, V. KONRÁDOVÁ ${ }^{1}$, J. ZOCOVÁ ${ }^{2}$ \\ ${ }^{1}$ Institute of Histology and Embryology, $2^{\text {nd }}$ Medical Faculty, \\ ${ }^{2}$ Department of Applied Mathematics and Computer Science, Faculty of Science, \\ Charles University, Praha, Czech Republic \\ Received November 11, 1999 \\ Accepted February 10, 2000
}

\section{Abstract}

Vajner L., J. Uhlík, V. Konrádová, J. Zocová: The Effect of Intravenously Administered Acetylcholine on the Glycoconjugate Composition in Goblet Cells of the Tracheal Epithelium in Rabbits. Acta Vet. Brno 2000, 69: 17-23.

To evaluate the influence of cholinergic stimulation on the composition of glycoconjugates in goblet cells, we studied the tracheal epithelium of rabbits 5 minutes and 20 minutes after i.v. administration of acetylcholine in doses $0.1 \mathrm{mg}$ and $0.5 \mathrm{mg}$, respectively. Using both conventional and lectin histochemistry, we compared the percentage of tracheal goblet cells containing neutral glycoconjugates to those containing total acidic glycoconjugates, sulphated acidic glycoconjugates, and sialylated acidic glycoconjugates. A conspicuous increase in percentage of neutral glycoconjugates-containing goblet cells and a decrease of sialylated glycoconjugatescontaining goblet cells occurred as early as 5 minutes after the administration of the lower dose and were recorded 20 minutes post exposure, too. Five minutes post exposure, the higher dose evoked a decrease in percentage of both neutral- and sialylated glycoconjugates-containing goblet cells. Twenty minutes after the administration of the higher dose, percentage of all studied elements reached values similar to those found in the lower dose group. The cholinergic stimulation did not cause total disappearance of both neutral- and sialylated glycoconjugates-containing goblet cells. Only the reaction of goblet cells 5 minutes after the administration of the higher acetylcholine dose differed quantitatively from the reactions in remaining experimental groups.

Airways' epithelium, cholinergic stimulation, glycoconjugates, lectin histochemistry

In our previous studies, we demonstrated that the goblet cells (GC) in the rabbit tracheal epithelium were overstimulated and damaged due to the intravenous (i.v.) administration of acetylcholine. An apocrine type of secretion and also chain exocytosis were found after the administration of both doses of acetylcholine. Twenty minutes after the administration of $0.5 \mathrm{mg}$ of acetylcholine, the degeneration of GC evoked massive differentiation of new secretory elements (Konrádová et al. 1996ab). Similar reaction of GC was also described by Specian and Neutra (1980) in the tissue culture of intestinal GC, and by Newman et al. (1996) in the tracheal epithelium of guinea pigs.

Tokuyama et al. (1990) and Fung et al. (1992) confirmed the stimulating effect of vagal control to the secretion of airways' GC and submucosal glands. Ramnarine and Rogers (1994) stressed non-adrenergic, non-cholinergic (NANC) neural mechanisms, coworking with neurogenic acetylcholine as "the secretion fine tuning". A direct effect of acetylcholine on tracheal secretory elements was further confirmed as a dose-dependent in studies by Kamijo et al. (1993), Woods et al. (1996), and Matera et al. (1998). Miyata et al. (1998) doubted the acetylcholine role in controlling production of high molecular weight-glycoconjugates in spite of the study by Steel and Hanrahan (1997) on GC of the tracheal epithelium in hamsters.

The presence of neutral and acidic sulphated and acidic sialylated glycoconjugates

Address for correspondence:

MVDr. Luděk Vajner, CSc.

Institute of Histology and Embryology

V úvalu 84, 15006 Praha 5-Motol, Czech Republic
Phone: +420224435982 (1)

Fax: +420224435820

E-mail.Ludek.Vajner@lfmotol.cuni.cz 
(GCCs) was widely evidenced in many species including humans (Lamb and Reid 1972; Jones and Reid 1978; Jacob and Poddar 1982; Spicer et al. 1983; Castells et al. 1990, 1991, 1992, 1994; Jeffery et al. 1992; Kim et al. 1997). Damjanov (1987) stressed the differences in the GCC composition among individual species. Jones and Reid (1978) and Jeffery et al. (1992) described the conspicuous increase up to total dominance of acidic sulphated GCCs in patients suffering from cystic fibrosis and bronchitis. Lamb and Reid (1972) and Damjanov (1987) held the decrease of acidic sialylated GCCs and the increase of acidic sulphated ones for a common reaction of the tracheal epithelium to general alteration. Miyata et al. (1998) described the protective effects of sialic acids on the airways' epithelium.

To complete our previous studies, we decided to study also the effect of i.v. administered acetylcholine on the composition of the mucus secreted by GC in the tracheal epithelium of rabbits.

\section{Materials and Methods}

In experiment, we used 16 SPF New Zealand White male rabbits (Charles River, Germany) of the average body weight $1,758 \pm 146 \mathrm{~g}$. Four healthy rabbits served as untreated controls. The remaining animals were divided in two groups of six rabbits and were treated intravenously with $0.1 \mathrm{mg}$ and $0.5 \mathrm{mg}$ of acetylcholine (Ciba, Niederwangen, Belgium), respectively. All experimental procedures were performed in animals under general anaesthesia using the i.m. administration of a mixture of ketamine and xylazine according to the certification of the Animals Protection Expert Commission of the Faculty.

The middle portions of tracheae between the $15^{\text {th }}$ and $20^{\text {th }}$ tracheal rings were sampled. The material was collected 5 and 20 minutes post exposure, respectively. The formalin-fixed samples were processed by the routine paraffin-embedding method. Serial sections 5-7 $\mu \mathrm{m}$ thick were made. The combined staining method of Alcian Blue (AB) at $\mathrm{pH} 2.5$ followed by PAS-reaction according to Mowry and Winkler (1956) was used to reveal both total acidic and neutral GCCs. Selective staining of acidic sulphated GCCs was obtained using AB at pH 1.0 (Kiernan 1981). To detect sialylated GCCs directly, the methods of in situ lectin histochemistry were used. At first, we used the Sata's modification (Sata et al. 1990) of digoxigenin-labelled lectin reaction, visualised by the alkaline phosphatase (AP)-X-phosphate (BCIP)-nitroblue tetrazolium (NBT) system (Boehringer Mannheim Biochemica, Germany). In this study, both Maackia amurensis agglutinin (MAA), detecting terminal Nacetylneuraminic acid (2-3) glycosidically linked to galactose, and Sambucus nigra (SNA) agglutinin, detecting terminal $\mathrm{N}$-acetylneuraminic acid (2-6) glycosidically linked to galactose or $\mathrm{N}$-acetylgalactosamine, were employed. The Tritrichomonas mobilensis lectin (TML) possessing the exclusive affinity to various modifications in linkages of both $\mathrm{N}$-acetylneuraminic and N-glycolneuraminic acids was also used (Babál et al. 1994, 1995, 1996ab). We modified the original Babál's method. After dewaxing and rehydrating, the endogenous AP was blocked and sections incubated with TML in the concentration $30 \mu \mathrm{g} / \mathrm{ml}$ for $60 \mathrm{~min}$. The non-specific binding sites to the primary antibody were blocked by 10 -minute submersion in $5 \%$ low-fat milk. Then the sections were incubated with the primary monoclonal antibody against TML, the supernatant fluid of the hybridoma culture (mouse-myeloma cell line P3-X63, clone B-VI-10C4) in the dilution 1:2. As the last step, the secondary polyclonal rabbit antibody against the whole molecule of the mouse $\mathrm{IgG}$, labelled with AP (Sigma-Aldrich Chemie, Deisenhofen, Germany) in the dilution 1:50 for 30 minutes, followed by BCIP-NBT visualisation, was used Blocking endogenous AP was verified by omitting the first step of the method. Specific lectin binding was verified by 15 -minute incubation of lectins with control substrates - transferrin and fetuin, preceding the incubation with sections. We evaluated only goblet cells containing well-developed granules with the positive reaction in each method used. The granules had to fill at least $2 / 3$ of the height of the epithelium. In each animal, at least 100 goblet cells were evaluated using all given methods.

For statistical evaluation, relative values of the six categories of GC, revealed by individual methods, were evaluated by the $\chi^{2}$ test of homogeneity in frequency tables, using the Yates' correction in low frequencies, and by the $F$-test.

\section{Results}

The tracheae of both control and treated rabbits were lined with pseudostratified columnar ciliated epithelium composed mostly of ciliated, goblet, and basal cells. The height of the epithelium was approximately $30 \mu \mathrm{m}$. The distribution of secretory elements was irregular.

Using conventional histochemical methods, the secretory elements revealed typical staining patterns according to the type of GCCs they contained. 
The appearance of goblet cells reacting with lectins used was the same in both control and treated rabbits. The positive reaction of MAA (Plate III, Fig. 1) was featured with the intensive staining of mucous granules in a goblet cell, either in the whole volume of a granule, or as a densely contrasted ring. The ciliary border was always densely stained, too. SNA-reaction depicted individual mucous granules as tiny rings, staining of the ciliary border was restricted to the close vicinity of apical surfaces of goblet cells (Plate III, Fig. 2). TML reacted in a similar way as MAA, but not so intensively (Plate III, Fig. 3).

In healthy control rabbits, we revealed $1.5 \pm 2.4 \%$ of goblet cells containing mucous granules with neutral GCCs and $71.9 \pm 6.4 \%$ of GC with acidic sulphated GCCs (Figs 4, 5). We calculated the percentage of the goblet cells containing acidic non-sulphated GCCs as $26.6 \pm 6.4 \%$ (Fig. 6). TML-positive sialylated GCCs were found in $26.6 \pm 11.5 \%$ of goblet cells, MAA-positive ones in $27.9 \pm 8.4 \%$, SNA-positive GCCs in $2.3 \pm 2.9 \%$, and both MAA- and SNA-positive GCCs in $30.2 \pm 9.6 \%$ of goblet cells (Figs 7, 8).

Five minutes after the administration of $0.1 \mathrm{mg}$ of acetylcholine, $6.5 \pm 8.4 \%$ of $\mathrm{GC}$ containing neutral GCCs and $84.5 \pm$ $36.0 \%$ of GC with acidic sulphated GCCs were found (Figs 4, 5). We calculated the percentage of the goblet cells containing acidic non-sulphated GCCs as $9.0 \pm 24.4 \%$ (Fig. 6). TMLpositive sialylated GCCs were found in $15.8 \pm 11.2 \%$ of goblet cells, MAApositive ones in $13.3 \pm 4.3 \%$, SNApositive GCCs in $1.8 \pm 6.2 \%$, and both MAA- and SNA-positive GCCs in $15.1 \pm 7.5 \%$ of goblet cells (Fig. 7).

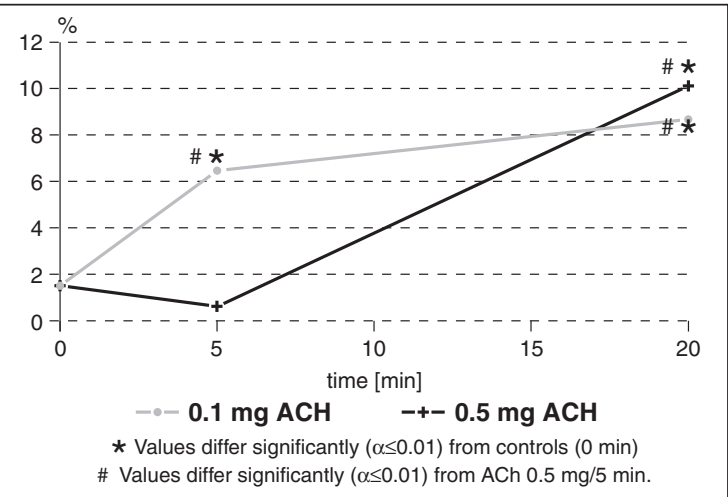

Fig. 4. Changes in percentage of tracheal goblet cells containing neutral glycoconjugates after i.v. administration of acetylcholine $(0.1 \mathrm{mg}$ or $0.5 \mathrm{mg})$. Conventional histochemistry.

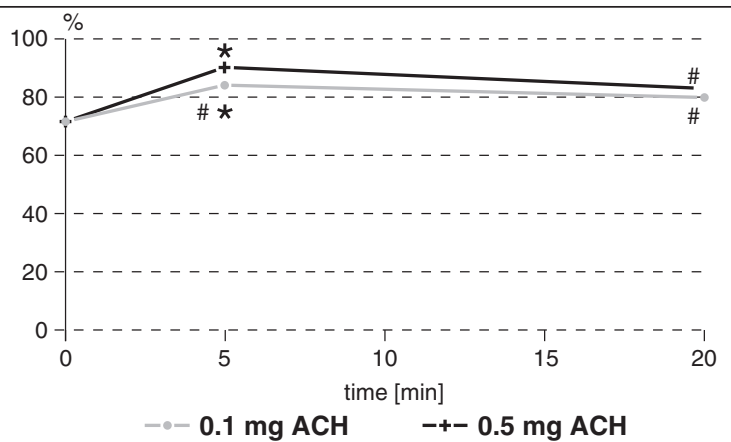

* Values differ significantly $(\alpha \leq 0.01)$ from controls $(0 \mathrm{~min})$ \# Values differ significantly $(\alpha \leq 0.01)$ from ACh $0.5 \mathrm{mg} / 5 \mathrm{~min}$.

Fig. 5. Changes in percentage of tracheal goblet cells containing acidic sulphated glycoconjugates after i.v. administration of acetylcholine $(0.1 \mathrm{mg}$ or $0.5 \mathrm{mg})$. Conventional histochemistry.

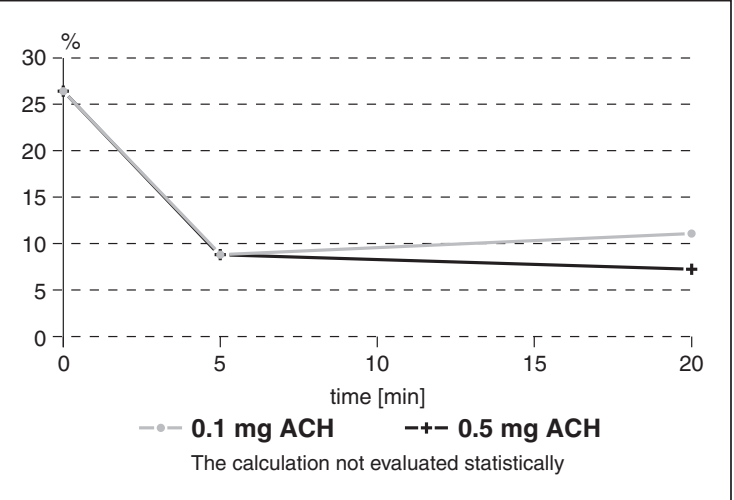

Fig. 6. Changes in percentage of tracheal goblet cells containing acidic non-sulphated (sialylated) glycoconjugates after i.v. administration of acetylcholine $(0.1 \mathrm{mg}$ or $0.5 \mathrm{mg})$. Calculation, conventional histochemistry. 


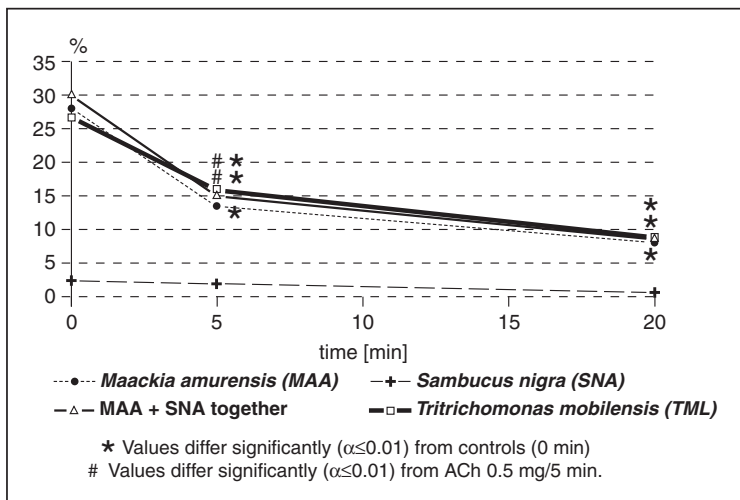

Fig. 7. Changes in percentage of tracheal goblet cells containing acidic sialylated glycoconjugates after i.v. administration of acetylcholine $(0.1 \mathrm{mg})$. Lectin histochemistry.

Twenty minutes after administration of this lower dose, we observed $8.7 \pm 6.6 \%$ of $\mathrm{GC}$ containing neutral GCCs and $80.1 \pm$ $37.9 \%$ with acidic sulphated GCCs (Figs 4, 5). We calculated the percentage of the goblet cells containing acidic non-sulphated GCCs as $11.2 \pm 34.9 \%$ (Fig. 6). TML-positive sialylated GCCs were found in $8.5 \pm 4.2 \%$ of goblet cells, MAA-positive ones in $7.9 \pm$ $6.1 \%$, SNA-positive GCCs in $0.5 \pm$ $1.2 \%$, and both MAA- and SNApositive GCCs in $8.5 \pm 7.2 \%$ of goblet cells (Fig. 7).

Five minutes after administration of $0.5 \mathrm{mg}$ of acetylcholine, we revealed $0.6 \pm 1.2 \%$ of GC containing neutral GCCs and 90.5 $\pm 4.8 \%$ with acidic sulphated GCCs (Figs 4,5 ). We calculated the percentage of the goblet

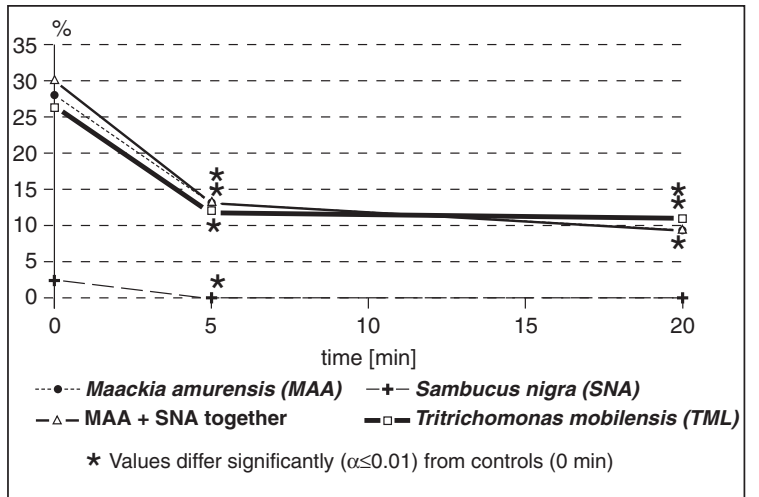

Fig. 8. Changes in percentage of tracheal goblet cells containing acidic sialylated glycoconjugates after i.v. administration of acetylcholine $(0.5 \mathrm{mg})$. Lectin histochemistry. cells containing acidic nonsulphated GCCs as $8.9 \pm 4.6 \%$ (Fig. 6). TML-positive sialylated GCCs were found in $12.2 \pm 3.5 \%$ of goblet cells, MAA-positive ones in $13.1 \pm$ $7.9 \%$, SNA-positive GCCs were not detected at all (Fig. 8).

Twenty minutes after administration of $0.5 \mathrm{mg}$ of acetylcholine, $10.1 \pm 10.8 \%$ of GC containing neutral GCCs and $82.7 \pm$ $41.3 \%$ with acidic sulphated GCCs were observed (Figs 4, 5). We calculated the percentage of the goblet cells containing acidic nonsulphated GCCs as $7.2 \pm 30.8 \%$ (Fig. 6). TML-positive sialylated GCCs were found in $10.8 \pm 23.4 \%$ of goblet cells, MAA-positive ones in $9.7 \pm 26.6 \%$, SNApositive GCCs were not detected (Fig. 8).

The statistical significance of differences between individual groups of goblet cells is given in Figs 4 - 8.

\section{Discussion}

The methods used allowed us to give the proportion of acidic sialylated glycoconjugates as either the difference of the percentage of total acidic and acidic sulphated glycoconjugates, or the direct sum of MAA- and SNA-detected glycoconjugates, or the direct result of TML detection, respectively. The relatively high concentration of TML was used because of rather lower sensitivity of our modification, compared to the original Babál's method (Babál et al. 1995, 1996 b).

In accordance with many authors (Lamb and Reid 1972; Jones and Reid 1978; Jacob and Poddar 1982; Spicer et al. 1983; Castells et al. 1990, 1991, 1992, 1994; 
Mandal and Mandal 1990; Jeffery et al. 1992), we found both neutral and acidic sulphated and acidic sialylated glycoconjugates in the mucous granules of goblet cells in the tracheal epithelium of the control rabbits. In experimental groups, we identified the same glycoconjugates, too. Compared to rats (Jones and Reid 1978), we observed the majority of acidic glycoconjugates to neutral ones, the same as the dominance of acidic sulphated glycoconjugates. The data obtained by both conventional and lectin histochemistry were almost identical.

The dynamics of changes in percentage of MAA+SNA-positive goblet cells followed the same dynamics in TML-positive goblet cells. In the lower-dose groups, the percentage of goblet cells containing the glycoconjugates with the terminal (2-6)-linked $\mathrm{N}$ acetylneuraminic acid did not reach the zero point even 20 minutes post exposure. On the other hand, such goblet cells were not detectable as early as 5 minutes post exposure and did not recover still 20 minutes after administration of the higher dose. The absence of goblet cells containing mentioned kind of acidic sialylated glycoconjugates could thus serve as a histochemical marker of the stimulation of tracheal secretory elements over the basal mucociliary function.

The change towards the dominance of acidic sulphated glycoconjugates, namely 5 minutes after administration of the higher dose of acetylcholine, was in accordance with studies of many authors on the influence of some noxae affecting the terminal glycosylation (Lamb and Reid 1972; Jones and Reid 1978; Damjanov 1987; Jeffery et al. 1992). Identified reaction time corresponded to the opinion that the sialylation belonged to the last steps in the glycosylation sequence (Castells et al. 1992). The proportion of goblet cells containing neutral, acidic sulphated, and acidic sialylated glycoconjugates was changed in individual experimental groups. SNA-detected acidic sialylated glycoconjugates were the only exception that disappeared completely after the administration of the higher dose of acetylcholine.

We arrived at the conclusion that the i.v. administration of acetylcholine affected the composition of glycoconjugates contained in goblet cells of the tracheal epithelium in rabbits and that the reaction of goblet cells 5 minutes after the administration of the higher acetylcholine dose differed quantitatively from the reactions in remaining experimental groups.

\section{Účinek intravenózně podaného acetylcholinu na složení glykokonjugátů sekretu pohárkových buněk v epitelu trachey králíků}

Studovali jsme tracheální epitel králíků 5 a 20 minut po i.v. podání acetylcholinu v dávkách 0,1 a $0,5 \mathrm{mg}$, abychom posoudili vliv cholinergní stimulace na složení glykokonjugátů obsažených v pohárkových buňkách. Porovnali jsme podíl pohárkových buněk obsahujících neutrální glykokonjugáty s podílem pohárkových buněk obsahujících celkové kyselé glykokonjugáty a určili jsme podíl těchto buněk obsahujících sulfonované a sialované kyselé glykokonjugáty za použití metod konvenční a lektinové histochemie. Již po 5 minutách po podání nižší dávky jsme zaznamenali významný nárůst podílu pohárkových buněk obsahujících neutrální glykokonjugáty spolu s úbytkem podílu pohárkových buněk obsahujících kyselé sialované glykokonjugáty. Tato změna trvala ještě 20 minut po aplikaci nižší dávky acetylcholinu. Vyšší dávka vyvolala po 5 minutách úbytek podílu pohárkových buněk s obsahem jak neutrálních, tak kyselých sialovaných glykokonjugátů. Po 20 minutách se podíly všech sledovaných pohárkových buněk blízily hodnotám zjištěným po podání dávky nižší. Cholinergní stimulace nezpůsobila úplné vymizení podílu pohárkových buněk s obsahem neutrálních nebo kyselých sialovaných glykokonjugátů. Pouze reakce pohárkových buněk 5 minut po podání vy̌šši dávky acetylcholinu se kvantitativně vymykala z jinak podobné dynamiky u obou dávek. 


\section{Acknowledgements}

We are grateful to Dr. Pavel Babál (University of South Alabama, Department of Pathology, Mobile, USA) for the gift of samples of both TML and primary monoclonal antibody to this lectin. This work was supported by the Grant Agency of Charles University (Grants $N^{\circ} 79 / 97$ and $N^{\circ} 185 / 98$, and by the research project of the Czech Ministry of Education No 11300003.

\section{References}

BABÁL, P., PINDAK, F. F., WELLS, D. J., GARDNER, W. A., Jr. 1994: Purification and characterization of sialic acid-specific lectin from Tritrichomonas mobilensis. Biochem. J. 299: 341-346.

BABÁL, P., ZAVIAČIČ, M., DANIHEL, L., GARDNER, W. A., Jr. 1995: Histochemistry of the novel lectin from Tritrichomonas mobilensis with specificity for sialic acid. Bratisl. Lek. Listy 96: 371-377.

BABÁL, P., GARDNER, W. A., Jr. 1996a: Histochemical localization of sialylated glycoconjugates with Tritrichomonas mobilensis lectin (TLM). Histol. Histopathol. 11: 621-631.

BABÁL, P., SLUGEŇ, I., DANIŠ, D., ZAVIAČIČ, M., GARDNER, W. A., Jr. 1996b: Sialic acid expression in normal and diseased human kidney. Acta Histochem. (Jena) 98: 71-77.

BARNES, P. J. 1993: Muscarinic receptor subtypes in airways. Life Sci. 52: 521-527.

CASTElls, M. T., BALlestA, J., PASTOR, L. M., MADRID, J. F., MARIN, J. A. 1990: Histochemical characterization of glycoconjugates in the epithelium of the extrapulmonary airways of several vertebrates. Histochem. J. 22: 24-35.

CASTElls, M. T., BALleStA J., MADRID, J. F., AVILÉS, M., MARTÍNEZ-MENÁRGUEZ, J. A. 1991: Characterization of glycoconjugates in developing rat respiratory system by means of conventional and lectin histochemistry. Histochemistry 95: 419-426.

CASTELLS, M. T., BALLESTA, J., MADRID, J. F., MARTÍNEZ-MENÁRGUEZ, J. A., AVILÉS, M. 1992 Ultrastructural localization of glycoconjugates in human bronchial glands: The subcellular organization of $\mathrm{N}-$ and O-linked oligosaccharide chains. J. Histochem. Cytochem. 40: 265-274.

CASTELLS, M. T., MADRID, J. F. AVILÉS, M., MARTÍNEZ-MENÁRGUEZ, J.A., BALLESTA, J. 1994 Cytochemical characterization of sulfo- and sialoglycoconjugates of human laryngeal glandular cells. J. Histochem. Cytochem. 42: 485-496.

DAMJANOV, I. 1987: Biology of disease. Lectin cytochemistry and histochemistry. Lab. Invest. 57: 5-20.

FUNG, D. C. K., BEACOCK, D. J., RICHARDSON, P. S. 1992: Vagal control of mucus glycoconjugate secretion into the feline trachea. J. Physiol. 453: 435-447.

JACOB, S., PODDAR, S. 1982: Mucous cells of the tracheobronchial tree in the ferret. Histochemistry 73: 599605.

JEFFERY, P. K., GAILLARD, D., MORET, S. 1992: Human airway secretory cells during development and in mature airway epithelium. Eur. Respir. J. 5: 93-104

JONES, R., REID, L. 1978: Secretory cells and their glycoproteins in health and disease. Brit. Med. Bull. 34: 9-16.

KAMIJO, A., TERAKAWA, S., HISAMATSU, K. 1993: Neurotransmitter-induced exocytosis in goblet and acinar cells of rat nasal mucosa studied by video microscopy. Am. J. Physiol. 265 (Lung Cell. Mol. Physiol. 9): L200-L209.

KIERNAN J. A. 1981: Histological and histochemical methods: Theory and practice. Pergamon Press, Oxford, 344 p.

KIM, K. C., McCRACKEN, K., LEE, B. C., SHIN, C.Y., JO, M. J., LEE, C. J., KO, K. H. 1997: Airway goblet cell mucin: Its structure and regulation of secretion. Eur. Respir. J. 10: 2644-2649.

KONRÁDOVÁ, V., UHLÍK, J., VAJNER, L., ZAJÍCOVÁ A., ZOCOVÁ, J. 1996a: Ultrastructure of the tracheal epithelium in rabbits after acetylcholine administration. Folia Biol. (Praha) 42: 261-265.

KONRÁDOVÁ, V., UHLÍK, J., VAJNER, L., ZOCOVÁ, J. 1996b: Reaction of the goblet cells to the cholinergic stimulation. Acta Vet. Brno 65: 175-180.

LAMB, D., REID, L. 1972: Acidic glycoproteins produced by the mucous cells of the bronchial submucosal glands in the fetus and child: A histochemical study. Brit. J. Dis. Chest 66: 248-253.

MANDAL, C., MANDAL, C. 1990: Sialic acid binding lectins. Experientia 46: 433-441.

MATERA, M.G., D'AGOSTINO, B., COSTANTINO, M., AMORENA, M., LUCARELLI, C., ROSSI, F. 1998 : Possible functional modulation by acetylcholine of nitric oxide on guinea pig isolated trachea. Life Sci. 62: 553559.

MOWRY, R. W., WINKLER, C. H. 1956: The coloration of acidic carbohydrates of bacteria and fungi in tissue sections with special reference to capsule of Cryptococcus neoformans, pneumococci, and staphylococci. Am. J. Pathol. 32: 628-629.

MIYATA, T., KAI, H., ISOHAMA, Y., TAKAHAMA, K. 1998: Current opinion of muco-active drug research: strategies and problems. Eur. Respir. J. 11: 480-491.

NEWMAN, T. M., ROBICHAUD, A., ROGERS, D. F. 1996: Microanatomy of secretory granule release from guinea pig tracheal goblet cells. Am. J. Respir. Cell. Mol. Biol. 15: 529-539.

RAMNARINE, S. I., ROGERS, D. F. 1994: Non-adrenergic, non-cholinergic neural control of mucus secretion in the airways. Pulmon. Pharmacol. 7: 19-33.

RAMNARINE, S. I., HADDAD, E.-B., KHAWAJA, A.M., MAK, J. C. W., ROGERS, D. F. 1996: On muscarinic 
control of neurogenic mucus secretion in ferret trachea. J. Physiol. 494.2: 577-586.

ROUMAGNAC, I., LABOISSE, CH. 1987: A mucus-secreting human colonic epithelial cell line responsive to cholinergic stimulation. Biol. Cell 61: 65-68.

SATA, T., ZUBER, C., ROTH, J. 1990: Lectin-digoxigenin conjugates: A new hapten system for glycoconjugate cytochemistry. Histochemistry 94: 1-11.

SPECIAN, R. D., NEUTRA, M. R. 1980: Mechanisms of rapid mucus secretion in goblet cells stimulated by acetylcholine. J. Cell. Biol. 85: 626-640.

SPICER, S. S., SCHULTE, B. A., THOMOPOULOS, G. N. 1983: Histochemical properties of the respiratory tract epithelium in different species. Am. Rev. Respir. Dis. 128: S20-S26.

STEEL, D.M., HANRAHAN, J.W. 1997: Muscarinic-induced mucin secretion and intracellular signalling by hamster tracheal goblet cells. Am. J. Physiol. 272: L230-L237.

TOKUYAMA, K., KUO, H.-P., ROHDE, J. A. L., BARNES, P. J., ROGERS, D. F. 1990: Neural control of goblet cell secretion in guinea pig airways. Am. J. Physiol. 259 (Lung Cell. Mol. Physiol. 3): L108-L115.

WOODS, B. A., NG, W., THAKORIAL, D., LIU, A. L., PERKS, A. M. 1996: Effects of acetylcholine on lung liquid production by in vitro lungs from fetal guinea pigs. Can. J. Physiol. Pharmacol. 74: 918-927. 
Plate III

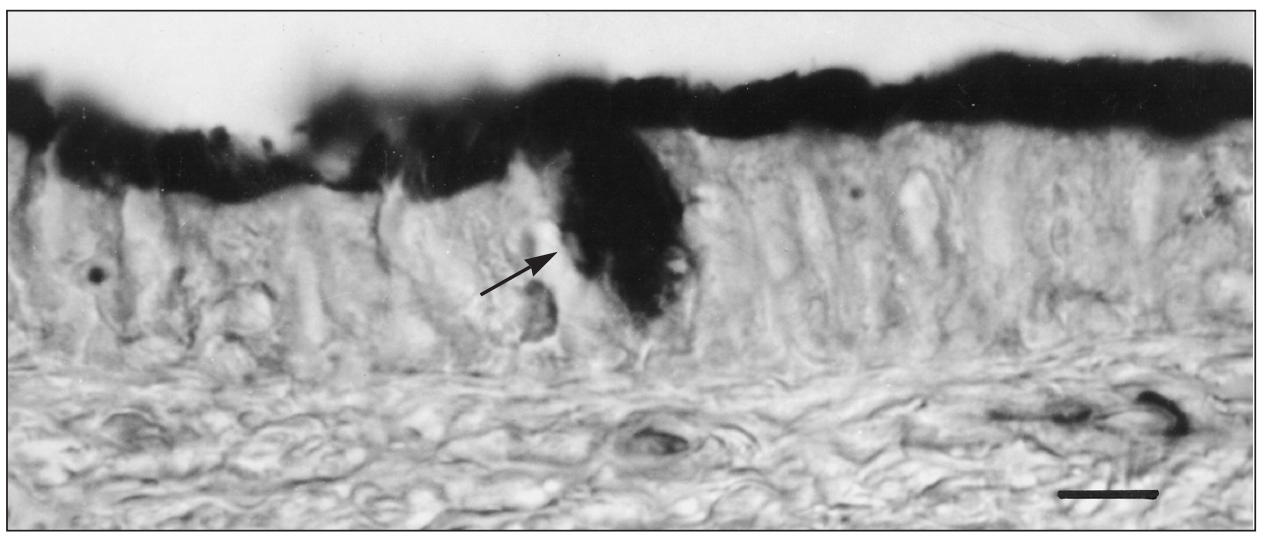

Bars are equal to $10 \mu \mathrm{m}$.

Fig 1. A goblet cell (arrow) in the tracheal epithelium of a control healthy rabbit. MAA reaction.

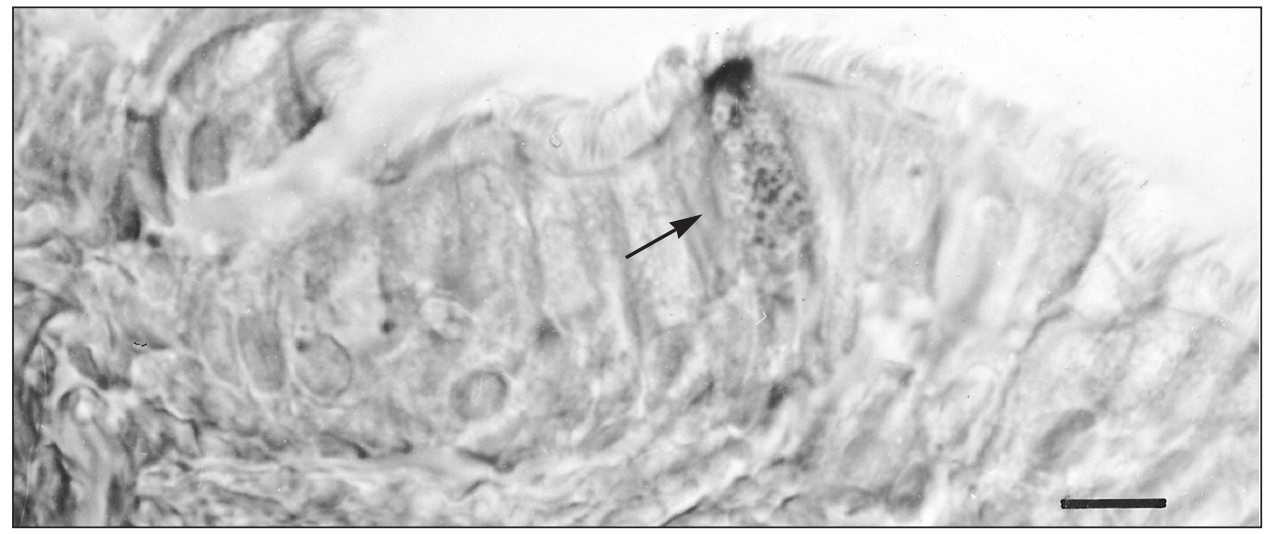

Fig 2. A goblet cell (arrow) in the tracheal epithelium of a control healthy rabbit. SNA reaction.

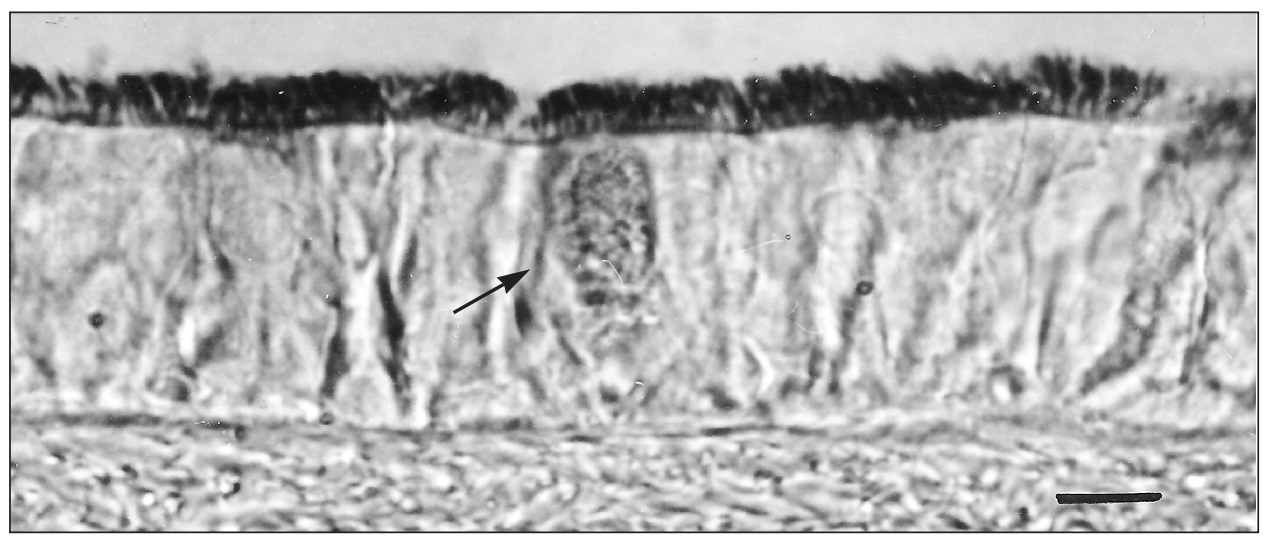

Fig 3. A goblet cell (arrow) in the tracheal epithelium of a rabbit, 5 min after administration of $0.1 \mathrm{mg}$ of acetylcholine. TML reaction. 